\title{
The Socio-Economic Role of Xate: A Case Study from a Returnee Community in the Maya Biosphere Reserve in Guatemala
}

\author{
Ingrid Nesheim (Corresponding author) \\ Centre for Development and the Environment, University of Oslo \\ PO box 1116, Blindern 0317 Oslo, Norway \\ Tel: 47-2285-8878 E-mail: ingrid.nesheim@sum.uio.no
}

\author{
Kristi Anne Stølen \\ Centre for Development and the Environment, University of Oslo \\ PO box 1116, Blindern 0317 Oslo, Norway \\ Tel: 47-2285-8980Ｅ-mail: k.a.stolen@sum.uio.no
}

Received: January 4, 2012 Accepted: January 31, $2012 \quad$ Published: March 1, 2012

doi:10.5539/jsd.v5n3p46

URL: http://dx.doi.org/10.5539/jsd.v5n3p46

\begin{abstract}
Migrant populations have been blamed for over-harvesting natural resources threatening the long-term viability of the natural resource base. It has been argued that they over-harvest because they lack skills and experience. Chamaedorea sp., is one of the few non-timber forest products with which a significant number of agricultural households in rural Petén supplement their income. This paper presents a case study of the harvest of three xate species and of the economic importance of xate among the returnees (migrants returning to their home country from exile) in the cooperative Unión Maya Itzá in the Maya Biosphere Reserve, Guatemala. This case study shows that xate represented an important economic asset in the community. The institutional and human resources in La Quetzal have been important for realizing the economic value of xate for the community; however, these resources have also contributed to realizing a sustainable management of the xate resource in the community.
\end{abstract}

Keywords: Xate, Non-timber forest products, Over-harvesting, Migrant populations, Institution building

\section{Introduction}

Hundreds of millions of people meet a significant portion of their subsistence needs and derive income from gathered plants and animal products (Ticktin, 2004; Nesheim et al., 2006; Bawa et al., 2007; Nyomora \& Mwasha, 2007). In the Petén region in Guatemala, non-timber forest products (NTFPs) have been exploited since the time of the Mayan civilization, and commercial forest extraction has for long contributed to rural people's livelihood. Xate, referring to several Chamaedorea sp. is the most important NTFP and a significant source of cash income for peasants in the forest areas of Petén (Reining et al., 1992; Nesheim et al., 2006; USAID, 2006). Exports of the leaves, which are used as green foliage in floral arrangments, have increased substantially since the 1960s (Schwartz, 1990; Salafsky et al., 1993; USAID, 2006; Wilsey \& Hildebrand, 2011). However, intense harvesting in Petén over a number of years has led to reduced harvests, concerns for future possible extraction, and the loss of biodiversity (Salafsky et al., 1993; Sánchez-Carillo \& Valtierra-Pacheco, 2003; Bridgewater et al., 2006).

The influx of migrant populations has been blamed for the over-harvesting of natural resources. It is argued that their lack of skills and experience threaten the long-term viability of the resource base (Browder, 1995; Cassels et al., 2005). Furthermore, migrants are said to have an expansionist attitude toward new land and to fail to consider the long-term effects of resource extraction and use (Pichon, 1997). We present in this paper a case of returnees (migrants returning to their home country from exile) with a unique history of institution building settling in a new natural environment with a strong community land-use regime (see also Bray et al., 2008). The returnees of this study established the cooperative Unión Maya Itzá (UMI hereafter) and constructed a new community named La Quetzal in 1996 within the multiple-use zone in the Maya Biosphere Reserve (MBR hereafter) in Petén, Guatemala. The location within the multiple-use zone implied that the use of the land had to be approved by CONAP (Consejo Nacional de Areas Protegidas), the national institution in charge of protected areas in Guatemala, and the 
community faced strong restrictions on land use. Hence, the forest management regime in the study area is regulated by the Forestry Law 1996 and by rules of CONAP and of the cooperative UMI.

As La Quetzal is located within the MBR, the area to be used for agriculture was limited, and the harvest had to be supplemented by forest products including xate, one of several Chamaedorea sp. These species turned out to be an important source of income for a number of people. In this paper, we analyse the importance of xate collection as a livelihood strategy and as a safety net both for different vulnerable groups and for gender dynamics in the society. The returnees in La Quetzal have a unique history of institution building and of development of social cohesion; we discuss the impact of this background and of this mixed governance regime, i.e. CONAP and UMI, for the xate harvest. La Quetzal is a rural peasant community like many others; yet, it is different from what is often associated with traditional peasant communities in Guatemala because the land is owned by a cooperative, the community has a high level of community organization, and it is located within the MBR.

\section{The Study Area}

The study was conducted in the Neotropical rainforest of the MBR, encompassing nearly $15,000 \mathrm{~km}^{2}$. The establishment of the MBR in 1990 on the Yucatan Peninsula was meant to stop both the ongoing land occupation by migrants and the subsequent deforestation and loss of biodiversity due to the conversion of forestland to agriculture. The MBR is divided into three zones that have different degrees of environmental protection: the core zone area (784,000 hectares) set aside for absolute protection of biodiversity; the multiple-use zone (800,000 hectares) where the oil and timber industries are permitted to operate and where sustainable use of forest resources by local people is allowed; and the buffer zone $(15 \mathrm{~km})$, a wide band of land that separates the MBR from the southern part of Petén, where all kinds of industrial and agricultural practices are allowed. The climate in the area is seasonal, with a dry season from November to May, while most of the annual rainfall $(1,738 \mathrm{~mm})$ takes place in the wet season from June to October, during which parts of the area are occasionally inundated (Salazar \& Cancino, 1998). Mean monthly temperatures range between $22^{\circ} \mathrm{C}$ and $29^{\circ} \mathrm{C}$, with annual maxima of $27-37^{\circ} \mathrm{C}$ and minima of $17-23^{\circ} \mathrm{C}$ (SEGEPLAN 1992).

La Quetzal is located within the multiple-use zone of the MBR, and the forest had to be cleared for its construction. The community was established with houses and associated home gardens, agricultural fields, and a grocery shop, located about a 6-hour drive from the nearest market. The soils are only moderately fertile; therefore, agricultural production was mainly intended for subsistence, and economic development was primarily associated with the exploitation of the forest. The returnees produced enough corn to eat and some to sell, but cash incomes were too low to cover what was needed to lead a decent life according to their own standards (Note 1) (Stølen, 2007). Since the returnees had lost all their belongings when they fled Guatemala in the early 1980s, they arrived in Petén with the little they had acquired during their years in Mexico (Stølen, 2007). Given that $80 \%$ of the estate was located within the multiple-use zone of the MBR, only a minor part could be used for agricultural purposes. People were in search of income-generating activities to be managed at the household level, and collection of xate was and is one of the few local sources of cash income. The xate species harvested in the community are Chamaedorea elegans Mart., known locally as xate hembra (female xate), C. oblongata Mart., known locally as jade, and Chamaedorea ernesti-augusti H. Wendl., known locally as cola de pescado (fish tail). These palm species are long-lived (15 years) (Hodel, 1992) and grow in the understory of the lowland primary and secondary rainforests of Belize, Guatemala, and Mexico.

\section{Methods}

\subsection{Social Data Collection}

The study on which this paper is based was part of a research project on causes and consequences of forced migration (Stølen, 2007). Anthropological fieldwork was carried out in La Quetzal over a period of three years (1998-2001) to grasp the dynamics of the return and resettlement process. This fieldwork, covering all the households in the community, consisted of a combination of participant observation and other data collecting techniques, ranging from informal conversations to more formal and focused interviews on specific topics. Informants were women, men, and children individually or in groups, in their homes, in the fields, at the laundry, washing clothes, walking along the roads or paths in the jungle, or in the 'house of the anthropologists'. Since the house was located in the centre of the community, people often dropped by when they finished their errands to rest before returning to their homes. Depending on the time of day, this was a quiet space for conversation. The anthropologist also attended a number of public events such as general assemblies and more selective gatherings, such as cooperative board or committee meetings and training sessions.

The socio-economic information directly related to xate was gathered in a similar way accompanying the xateros (xate harvesters) in the forest, in their homes, and in the cooperative warehouse, where they classified and 
delivered xate bundles to cooperative employee in charge of the xate trade. Informal conversations as well as more formal interviews were undertaken with the different actors involved: the xateros (eleven men and eight women), the xate manager (a cooperative employee in charge of buying from the xateros and selling to the buyers), and the merchants. In addition, we studied closely the documents where all the commercial xate activities of the cooperative had been reported in the years 1998-2000. The xateros were selected on the basis of age and sex, and represented households who were cooperative members and households who were not.

\subsection{Environmental Data Collection and Data Analysis}

Environmental data were collected partly on land owned by the cooperative UMI and partly in an adjacent protected area of the MBR. Five permanent plots, each $100 \times 100 \mathrm{~m}$, were selected within $6.5 \mathrm{~km}$ in the south-western part of the MBR in year 2000 (Figure 1). To determine Chamaedorea sp. population densities in the different forest types within the study area (see, Jones \& Gorchov, 2000; Penn et al., 2009), two plots were selected in a logged area (Logging 3 and Logging 4 plots), two plots were placed in the protected part of the reserve (Reserve 1 and 2 plot), and one was placed in the higher terrain in a karst-range topography partly with slopes close to the settlement (Settlement 5 plot). The Reserves 1 and 2 and the Logging plots 3 and 4 were placed a few hundred metres apart, in gently undulating, poorly drained terrain of low fertility. The Settlement 5 plot was placed on well-drained soils in an area close to the settlement, and was used by men, women, children, and older people in the village. All the plots experienced drought in the dry season. Each plot was divided into 100 subplots of $10 \times 10$ $\mathrm{m}$. The subplots were used as basic units for recording Chamaedorea sp., number of adult harvested plants, and number of cuts. Adult (harvestable) and juvenile xate (small non-harvestable) individuals were enumerated.

A harvest index (H.I.) was calculated as the mean of the number of cut leaves to the number of harvested plants. A rough measure of harvest pressure is the mean number of cut leaves per plant (Reining et al., 1992), and may serve as a comparison to the recommended sustainable level (1-2 leaves cut per plant).

\section{Results}

\subsection{The History and the Institutional Context of La Quetzal Returnee Community}

The returnees arrived as an organized group of approximately 1,200 people, being part of a collective return movement supported by international organizations, such as the UN and NGOs (Van der Vaeren, 2000; Stølen, 2007). Already a year before their arrival, they registered as a cooperative to facilitate the purchase of land and other preparations for the return. Their decision to organize as a cooperative was based on a number of considerations. To obtain the credit to buy the land, the refugees (Note 2) were obliged to establish some kind of association qualified to claim legal status (personería jurídica). The cooperatives, as a form of organization, was strongly recommended by leaders and advisors of the refugees, but was also welcomed by the refugees themselves.

The majority of the returnees in La Quetzal had lived in cooperatives before going into exile. They had experienced the advantages of this kind of organization with regard to the development of social services, the marketing of products, and negotiation with state and non-state agencies. After visiting farms for sale in different parts of the country, representatives of the refugees selected La Quetzal, an abandoned farm in the MBR of Petén, as their new site of residence. However, the location within the MBR created a number of challenges and constraints regarding land use and sustainable development of natural resources. According to the Guatemalan Forestry Law 1996, which stressed forest conservation and collaboration with municipal governments, the use and the exploitation of forests must respect an area's restrictions (Ferroukhi \& Echeverría, 2003), including prohibitions against cultivation in core areas of protected areas. About $80 \%$ of the cooperative UMI was protected area. It is CONAP which sets the norms for forest management and provides the exploitation permits and five-year detailed forest management plans. However, the ideas about environmental protection were not new to the returnees. During their time as refugees in Mexico, they had contact with international aid and solidarity organizations that introduced them to new ideas and knowledge, such as sustainable resource management, which was a central concern during the planning and preparation for their return to Petén.

To understand the social organization of the returnee community it is important to make a distinction between the community of La Quetzal and the cooperative UMI. While the community of La Quetzal comprises all the inhabitants regardless of age or sex, the cooperative comprises only its members, defined according to its statutes. Most members were adult married men and heads of household. There were only two female members; their husbands are migrants abroad. However, not all heads of household in La Quetzal were cooperative members. The inhabitants are in this paper divided into two categories according to their relationship with the cooperative: A total of 168 were cooperative members, and approximately 45 were pobladores, most of the latter ex-members of the cooperative. They withdrew from the cooperative in 1997 after successful negotiations with the government, who promised to give them land free of charge in another part of Petén as compensation for land lost when they went 
into exile. Those who continued as cooperative members could not claim compensation for land lost, because they had not obtained property rights when they left Guatemala. The pobladores remained in the village while their new sites of residence were being identified and prepared for settlement. Pobladores were also those who later decided to settle in La Quetzal; new settlers did not automatically receive membership since new members were accepted only when old ones resigned or left. Few, however, found the pobladore status attractive as it implied limited access to both resources and important decision-making. While cooperative members were assigned five hectares for agriculture, consisting of two plots of two hectares each for milpa (maize field) and one hectare of swampland for rice production, the pobladores received only two hectares. The pobladores benefited from some of the services such as healthcare and education, but did not participate in the cooperative's economic activities, for example, timber extraction, which was planned to be the main future economic activity. On the other hand, pobladores were exempt from cooperative commissions and most of the heavy work obligations of cooperative members. Except for this division of land area among the cooperative members and the pobladores, the economic level among the returnees was about the same when arriving in the community.

The level of activity within the cooperative is high and varied. We registered 14 committees, responsible for the following activities: collective work for the cooperative, agriculture, forestry, marketing, raising poultry, growing vegetables, beekeeping, tailoring, harvesting xate, administering credit, arranging transport for people and goods, managing water projects, eco-tourism, and elaboration of projects. Several committees work at the community level representing certain segments of the population, referred to as sectores (sectors). They are six altogether and comprise the following: women, education promoters, health promoters and midwives, parents of families, youth, and catechists. The women's sector, the largest by far, includes Ixmucané - a women's organization - established in Mexico in 1993 to enhance women's participation in the returnee community.

\subsection{The Institutional Context of Xate}

The land located within the MBR is used for extraction of timber and NTFPs, xate being the most important. The extraction of both timber and NTFPs is subject to strict approval by CONAP. However, while timber extraction is carried out by the cooperative, according to a plan approved by CONAP and based on a communal forestry concession to benefit only cooperative members, NTFP extraction (via a license) is open to all the community's inhabitants. Through this license, the inhabitants gained access to the harvest of NTFPs in exchange for fees and protection responsibilities. The xate licence obtained from CONAP had to be renewed every second month; renewal involved a one-day inspection. The licensing application was initiated by a three-day course organised by Centro Maya a few months after the arrival. The teachers were experienced xate collectors. The course had 24 participants: 5 women and 19 men. They were taught how to recognize the species and how to harvest without damaging the plant. They were also told not to cut immature leaves, or leaves with spots, which in any case would be rejected by the buyers. Another course was supposed to be organised, but according to the xate manager, this has not been necessary, because those who participated in the first course passed the knowledge on to others. The xate manager remarked that in the beginning, a number of xate leaves were rejected because of deficient quality, but people learnt from experience, and the rejection rate was soon radically reduced. Currently, rejection mostly involved leaves harvested by children or people who were new collectors.

In 2001, the cooperative UMI joined the Association of Forest Communities of Petén (ACOFOP), an entity established in 1995 to promote socio-economic development and an improved quality of life through sustainable forest management within the MBR (see also, Taylor, 2010).

The cooperative raised a xate warehouse in the centre of the community, where the collectors arrived with their bundles on Friday afternoons to sell their products. On Saturday mornings, the buyer arrived with a pick-up truck to take the product to exporters. Since the price paid to the cooperative was higher than the one paid to the collectors, the cooperative received a share each time a xatero sold his bundles of leaves, and the cooperative earned an increasing amount on this xate business, starting at US\$459 in the first year (1996-97) and increasing to US\$2,624 in 2000. Thereby, xate was a source of income for the peasant households as well as for the cooperative.

\subsection{Xate Collection in La Quetzal}

Xate was collected individually or in small family groups and represented a particularly attractive source of income for returnee families. First, it required no investment or preparatory labour input; the xate plant exists in the wild ready to be harvested. Second, the plant's proximity to La Quetzal allowed for flexibility. For example, xate collecting could be combined with other household or village activities, which was especially advantageous for women and children, who could spend only a few hours collecting after finishing household chores, or classes in the case of schoolchildren. Third, unless collecting is done on a larger scale resulting in bundles too heavy to carry on the back, no expensive equipment is needed, only a small knife for cutting the leaves. Xateros cut one or two 
leaves from each plant as they walk through the forest, but leave the plant alive. Once collected, the leaves were brought back to the village, classified, tied into bundles of 100 leaves, and stored in the collectors' homes until delivered to the xate merchant on Fridays.

The xate manager estimated that the majority of households, about $70 \%$, had sold xate occasionally and that almost half, $40 \%$, sold xate regularly. The number of people selling xate each time the xate merchant came to the community varied from 3 to 90 , with a mean of 31 in 1998, increasing to 36 in 1999. Xate was harvested year round, but there was a seasonal trend in that most xateros collected around Christmas or New Year, and during -July-August (Figures 2a and 2b). For the three years 1998-2000, sales peaks (measured in bundles sold) occurred in January and February, again in June, July, and August, and again in November and December (Figure 2a). These peaks followed the same pattern for all three xate species each year. This pattern of high xate activity was associated with months of few agricultural activities and with school holidays, hence labour resources became available in both these periods. Not surprisingly, the number of people selling xate corresponds closely to the number of bundles sold (Figures 2a and 2b). During the high season in January and February, at the peak, 90 people per day sold xate, while the norm at high season were 40 people selling, increasing to around 50 in 1999. The number of people selling xate increased from 1998 to 1999. Most xateros were men; in 1998, men were recorded as selling xate 1,304 times (each time a man was recorded selling xate summed over the year), and in 1999, 1,550 were recorded as selling xate. However, a substantial number of women also collected xate: 113 in 1998 and 159 in 1999. The 'account book' indicated that every time the xate merchant appeared in the community (about 45 times yearly), some women sold xate. The authors did not observe anything which could indicate that the names recorded in the account book did not represent the respective xate collectors.

The informants interviewed reported that an average day of harvesting yielded 600 leaves of each species (see also, Reining \& Heinzman, 1992), providing a daily income of US\$2.00. At harvest peaks, when a total of $600-800$ bundles of xate were sold (Figure 2a), daily incomes were higher for most xateros, though lower than the daily salaries paid in the area for labour, ranging from US\$2.60 to US\$3.30. Recent information (2011) states that xate collection in 2011 represents a daily income of about US\$5.00 (email contact with CONAP, 2011). This number, however, refers to an income earned by those who could use a whole day to collect xate, that is, a minority of the people in the community. Important groups, like women and youth, but also many men, typically collected xate for half a day or for a few hours between other chores.

\subsubsection{The Role of Xate for Different Groups in the Community}

The value of xate in La Quetzal should be seen in the context of a community where most people survive on what is produced from the land, either in the form of agricultural production or in the form of NTFPs such as xate (Nesheim et al., 2006). Few people worked away from the farms because non-farm jobs were available only in places very far from La Quetzal. To understand the role of xate in the community, it is essential to recognize that xate collection had different functions for different groups. For the cooperative members, xate collection was an important strategy to meet urgent (unexpected) demands for cash that could be used, for example, to buy school utensils or clothes, and as insurance in case of crop failure. In general, however, they obtained enough food and even some cash from selling crops such as chilli and pepitoria, which were sold to ambulant merchants. Available time was the key factor limiting xate collection, since most labour resources had to be used on agriculture or on obligatory work in the cooperative. In fact, Figures $2 \mathrm{a}$ and $2 \mathrm{~b}$, illustrate a clustering of xateros and bundles sold during the months with less agricultural work demand, that is, late December-January and July. Xate collection was not identified as a coping strategy by the cooperative members, because they had enough land to cover their subsistence needs, but rather as an important opportunity to get some extra money for clothes, school equipment, and other necessities.

For the pobladores households, who had only two hectares of agricultural land compared to the five hectares of the cooperative members, the situation was quite different. For several, xate collection represented an important part of their livelihood diversification strategy (see, Pattanayak \& Sills, 2001; Pyhala et al., 2006; Delacote, 2007). A number of pobladores collected xate year round to meet household subsistence needs. On their two hectares of land, they gave priority to cultivating corn for their own subsistence, but production was not always enough to cover their subsistence needs, particularly those of large families (see Carr, 2008). Also, the pobladores had more available labour time, as limited agricultural land demanded less labour input, and they did not participate in the collective work of the cooperative. Opportunities to earn an income in the community were scarce; therefore, xate collection represented and important income generating strategy for most pobladores. Typically, pobladores went away for a few days to harvest xate in more distant areas with high xate densities, taking a mule or a horse to carry the bundles of leaves back home. Commonly, however, people in the community collected xate on a daily or hourly basis. 
Income generating activities in the community were even more limited for women than for men, because according to the sexual division of labour, women were not permitted to do many kinds of work. Men worked in agriculture and other economic activities within the frames of the cooperative (if they were members), while women were responsible for childcare and housework, which were extremely labour intensive because running water and electricity were lacking. Both chores heavily constrained women's participation outside the household. Whenever they left home, they had to take their children with them or depend on female relatives to babysit. Xate collection, which could be done relatively close to home and whenever the women had spare time, represented a unique opportunity for them to earn an income. Moreover, most women themselves take the leaves they collect to market, receive payment, and control how the money is used. The extra income generated from xate collection by the women was used on clothes, kitchen supplies, and medicines for the children. Typically, this collection rather represented a possibility for individuals to earn money for personal spending. However, women who were most active in xate collection were those in households were the men were sick or disabled, thus having limited working capacity.

Xate collection by youths was similar to that of women, and it was quite common for schoolchildren to accompany their mothers when collecting. Xate collection could easily be combined with school attendance and homework, and it was a common activity for youths during school vacations. Xate represented an opportunity for youths to buy things they wanted for personal enjoyment, such as football shoes or soda. For many, in particularly young boys, this was a common strategy; a not uncommon phrase in the community could be, 'Next week I have to collect xate to buy ...'

\subsection{Xate Distribution in the Study Area}

The total density of xate in all plots was 3,612 individual plants. The density, however, varied greatly among plots, and the highest number of plants was found in the Settlement 5 plot situated close to the settlement area on well-drained soils (Table 1). The logging and the reserve plots situated in the low area with less well-drained soils were recorded as having a lower xate density.

Chamaedorea elegans had the highest density in the Settlement 5 plot, with $98 \%$ presence in the subplots: It occurred in $67 \%$ of the subplots in the Logging 3 plot, in $49 \%$ of the subplots in the Logging 4 plot, and only at low densities in the Reserve plots. The density within each subplot varied between zero and nine plants (juvenile and adults) within the logging plots, and between zero and 33 plants in the Settlement 5 plot. C. oblongata occurred in $99 \%$ of the subplots within the Settlement 5 plot; it had intermediate levels in the Logging plots 3 and 4 (72 and $96 \%$, respectively), and the lowest occurrence was recorded in the reserve plots 1 and 2 (54 and 70\%, respectively).

The great difference in Chamaedorea sp. density between the well-drained Settlement 5 plot and the other plots in lower terrain of poorly drained soils is most likely due to differences in topographic - edaphic factors, factors which are known to have great impact on density patterns of palm species (Clark et al., 1995; Svenning, 1999; Penn et al., 2009), and not caused by harvest pressure - that is, there were no cuts in the Reserve plots, and relatively few in the Logging plots. That xate occurs in habitats of well-drained soils (such as the soil in the Settlement plot) is reported in several other studies (Hodel, 1992; Reining et al., 1992). In fact, Jones and Gorchow (2000) and Penn et al. (2009) show that in favourable environments, densities can reach more than 5000 palms $/$ ha, while in less favourable areas xate occurrences were less than four per plot (with even lower occurrences in certain areas).

\subsection{The Xate Harvest Pressure in the Study Area}

Over the whole study area, there were relatively few juvenile xate plants (seedlings were not registered). The highest density of juveniles in subplots ranged from 10 (C. elegans) to 15 (C. ernesti-augusti) and 18 ( $C$. oblongata), while mean numbers for these three xate species were $3,3.5$, and 5 juveniles, respectively, in subplots. The distribution of adults and juveniles in the study area may indicate that the demographic structure of these species consists of a larger proportion of adults and relatively few juveniles (See also, Endress et al 2004). For most xate species, the proportion of adult plants was much higher (around 70\%) than that of juveniles (around 20\%) (Table 2). The densities of juvenile xate species were positively correlated with adult xate densities. Interestingly, the H.I., namely the mean number of leaves cut per harvested plant in a subplot, was not positively correlated with juvenile density, nor adult xate density for any of the three xate species (Figure 3). The H.I. shows no consistent pattern across the five plots, but there is a tendency for the harvest level to stabilize at about two leaves cut per plant, the recommended sustainable level (Figure 3). No harvest occurred in the reserve plots, while the percentage of the xate species harvested in the Logging and the Settlement 5 plots varied, but in no conflict with the norm that $20 \%$ should be left for regenerating purposes (Table 2). 
A few guidelines have been developed to ensure sustainable harvesting (so-called low-impact harvesting): (i) 20\% of the plants should be left without leaf cutting in order to allow the plants to regenerate (Sánchez-Carillo \& Valtierra-Pacheco, 2003) and (ii) only one or two leaves should be cut per individual (O'Brien \& Kinnaird, 1996). In the cooperative UMI, the percentage of plants harvested in all plots was low, well below the norm that $20 \%$ of the plants should be left unharvested. Though in some subplots more than one or two leaves were cut, the main trend was that this rule was followed. Furthermore, there were few indications of unsustainable practices and degraded forest due to xate collection (Personal observation, 2000; Rainforest Alliance, 2006; Gomez \& Mendez, 2007), even in the area situated close to the community centre, where all members of the community (children, women, and men, including the more inexperienced harvesters more likely to damage or kill the plant) collect xate (See, Reining et al., 1992). The fact that the H.I. did not correlate with either the number of adults or the number of juveniles may indicate that xate densities at the plot level were not determined by harvest pressure, but rather by other micro level factors such as drainage levels, ecological competition, dispersal methods, and human activity (Penn et al., 2009).

\section{Discussion}

This case study clearly shows that xate represented an important economic asset in the community, a finding which is supported by others, including recent studies (Gomez \& Mendez, 2007). Agricultural production is the preferred source of subsistence; therefore, the housholds' land and the land's potential for agricultural production are negatively associated with the importance of NTFPs (xate) in a household's livelihood strategy. However, agricultural production is more affected by drought, seasonal flooding, and crop diseases than is harvesting of NTFPs, because generally, NTFPs are less affected by the same factors. Hence NTFPs may serve as a 'natural insurance' for people living on the forest fringes (Pattanayak \& Sills, 2001). Land, however, is a limited resource for all households, as are labour resources (see also, Carr, 2008), whereas cash is in constant demand. There are few other opportunities to earn cash income. Two factors, access to land and availability of labour resources, determine the need and the possibility, respectively, to collect xate for income generation.

The possibility to earn money through xate collection was especially important for women and youths, who in the forest margins have no other alternatives to earn money. Xate collection may for these groups contribute to empowerment, which is related to earning money for personal use. Traditionally, women working in the forest is rare (Carr, 2006; Nesheim et al., 2006; Stølen, 2007); however, recent studies from the Petén report that women are being involved in xate collection (New Agriculturist, 2010; Rainforest Alliance, 2010).

Several papers have argued that collection of NTFPs leads to over-exploitation of the resource (Crook \& Clapp, 1998; Endress et al., 2004) and that the economic value is low (Angelsen \& Wunder, 2003; Sunderlin et al., 2005). Certain factors associated with the particular situation in La Quetzal, however, contribute to the success story of xate commercialization: 1. A well-functioning local marketing system. The product can be delivered locally once a week, being picked up by merchants arriving in the community. No means of transport are needed; 2. Xate is free and available in the vicinity. Only a small knife is needed to cut xate, it is available in the neighbourhoods, and the product can be stored without special requirements; 3 . The cooperative provides institutional capacity. The xatero does not have to negotiate with the xate merchant, the terms for the commercialisation of xate are determined on the cooperative level, and the license for collecting is provided for all members of the community. Pyhälä et al. (2006) emphasise that the capability to benefit from resources is related to institutional and social structures that mediate resource use. They further argue that poorer social groups do not have the capital or labour to commercialize their products; in La Quetzal, the poor groups, (e.g. pobladores), benefit from the institutional capacity of the cooperative; 4 . The capacity building of the returnees and the location within the MBR. The institutional and human resources in La Quetzal have been important for realizing the economic value of xate for the community; however, we argue these resources have also contributed to realizing sustainable management of the xate resource in the community.

The field work on which this paper is based does not present evidence for a sustainable harvest in La Quetzal, because the area covered is too small and because of lack of replicated annual monitoring. However, the case study indicates that the recommended harvest practices (Radchowsky et al., 2004) - only two cuts per plant, and that harvested leaves should only be of high quality (Figure 2a, and communication with the xate agent) - were generally followed.

A recent ACOFOP report by Gomez and Mendez (2007) stated that the cooperative UMI had made significant achievements in developing their institutional arrangements and in their managing of the forest production. The report emphasised that UMI maintains strong social cohesion, which contributes significantly to strengthening community management and the residents' social welfare (Gomez \& Mendez, 2007). The governance regime of 
the forests of UMI is similar to that of many farmers in the MBR (Carr, 2008): They must follow rules of the Forestry law and of CONAP. However, there seems to be a large difference between the level of institutional support provided to the farmers' households as referred to by Carr (2008), and the level of such support provided to farmers' households in La Quetzal. Carr (2006; 2008) argues that 'little has been provided to the farmers in the way of technical assistance, credit or market strategies to promote sustainable agricultural management', in contrast to the situation of the farmers in UMI, where assistance by NGOs and international and state organizations has been quite extensive. The promulgation of the 1996 Forestry Law opened new possibilities for the municipal governments to participate more actively in forest resource management (Ferroukhi \& Echeverría, 2003; Andersson et al., 2006); however, several authors argue that limited economic resources following this decentralization strategy have in many cases resulted in deforestation (Clark, 2000; Carr, 2008; Ybarra, 2009).

\section{Conclusion}

Unlike most cases, which concern communities with a long tradition in the area, this case concerns a relatively newly established returnee community with a unique history of institution building, of developing social cohesion, and of implementing sustainable development practices. The institutional activity and organizational levels, 14 committees working within the frames of the cooperative in 2000 , are far greater than what is common in agro-industrial cooperatives in Guatemala. We argue here that the institutional strength of this cooperative is a reflection of its members' refugee past and their location within the core area of the MBR. As returned refugees, they received donor attention and support that have not been granted to communities of people who remained in Guatemala during the armed conflict. Through the participatory organization (the cooperative UMI established in the refugee camps) and through more formalized training by aid organizations, the refugees learnt new skills as well as new techniques of governance. They also developed a certain level of environmental awareness (Stølen, 2007). That level of awareness was enhanced by the cooperative's location within the MBR (implying heavy constraints on land use) and by legal incentives for sustainable practices.

The location and the incentives have helped this community to develop strong local-level governance institutions, and those institutions help to ensure the sustainable use of natural resources. Strong local institutions are important for sustainable forest management, but also to ensure economic development for local communities, pointing to the need for institution building particularly in agricultural frontiers where deforestation is high and livelihood options are few.

\section{Acknowledgements}

The authors would like to thank the people in La Quetzal community (the cooperative Unión Maya Itzá) for their hospitality and assistance during fieldwork, and in particular Dora Alicia for valuable help and companionship in the field. The authors thank the organization Centro Maya, the Biology Department at the University of San Carlo, and CONAP, for assistance and collaboration when in Guatemala. We would also like to thank Mariel Augilar Støen for valuable comments and suggestions to improve the quality of the paper.

\section{References}

Andersson, K. P., Gibson, C. C., \& Lehoucq, F. (2006). Municipal politics and forest governance: Comparative analysis of decentralization in Bolivia and Guatemala. World Development, 34 (3), 576-595. [Online] Available: http://libres.uncg.edu/ir/uncg/f/F_Lehoucq_Municipal_2005.pdf

Angelsen, A., \& Wunder, S. (2003). Exploring the forest-poverty link: key concepts, issues and research implications. CIFOR Occasional paper. Center for International Forestry Research, Bogor, Indonesia. [Online] Available: http://www.cifor.org/publications/pdf_files/OccPapers/OP-40.pdf

Bawa, K. S., Joseph, G., \& Setty, S. (2007). Poverty, biodiversity and institutions in forest-agriculture ecotones in the Western Ghats and Eastern Himalaya ranges of India. Agriculture Ecosystems \& Environment, 121 (3), 287-295. http://dx.doi.org/10.1016/j.agee.2006.12.023

Bray, D. B., Duran, E., Ramos, V. H., Mas, J. F., Velazques, A., McNab, R. B., Barry, D., \& Radachowsky, J. (2008). Tropical Deforestation, Community Forests, and Protected Areas in the Maya Forest. Ecology and Society, 13

[Online]

Available:

http://www.cifor.org/nc/online-library/browse/view-publication/publication/2711.html

Bridgewater, S. G. M., Pickles, P., Garwood, N. C., Penn, M., Bateman, R. M., Morgan, H. P., Wicks, N., \& Bol, N. (2006). Chamaedorea (Xate) in the Greater Maya Mountains and the Chiquibul Forest Reserve, Belize: An economic assessment of a non-timber forest producy. Economic Botany, 60 (3), 265-283. http://dx.doi.org/10.1663/0013-0001(2006)60[265:CXITGM]2.0.CO;2 
Browder, J. O. (1995). Colonization and environment land settlement projects in Central-America - Jones, JR. Latin American Research Review, 30 (3), 123-137. [Online] Available: http://www.jstor.org/stable/pdfplus/2503982.pdf

Carr, D. (2006). A tale of two roads: Land tenure, poverty, and politics on the Guatemalan frontier. Geoforum, 37, 94-103. http://dx.doi.org/10.1016/j.geoforum.2005.02.007

Carr, D. L. (2008). Farm households and land use in a core conservation zone of the Maya Biosphere Reserve, Guatemala. Human Ecology, 36 (2), 231-248. http://dx.doi.org/10.1007/s10745-007-9154-1

Cassels, S., Curran, S. R., \& Kramer, R. (2005). Do migrants degrade coastal environments? Migration, natural resource extraction and poverty in North Sulawesi, Indonesia. Human Ecology, 33 (3), 329-363. http://dx.doi.org/10.1007/s10745-005-4142-9

Clark, C. (2000). Land tenure delegitimation and social mobility in tropical Peten, Guatemala. Human $\begin{array}{lllll}\text { Organization, } & 59 & \text { (4), } & 419-427 . & \text { [Online] }\end{array}$ http://www.metapress.com/content/t871n738g1448401/fulltext.pdf

Clark, D. A., Clark, D. B., Sandoval, M. R., \& Castro, C. M. (1995). Edaphic and human effects on landscape-scale distributions of tropical rain forest palms. Ecology, 76, 2581-2594. http://dx.doi.org/10.2307/2265829

Crook, C., \& Clapp, R. A. (1998). Is market-oriented forest conservation a contradiction in terms? Environmental Conservation, 25 (2), 131-145. http://dx.doi.org/10.1017/S0376892998000186

Delacote, P. (2007). Agricultural expansion, forest products as safety nets, and deforestation. Environment and Development Economics, 12, 235-249. http://dx.doi.org/10.1017/S1355770X06003482

Endress, B. A., Gorchov, D. L., \& Noble, R. B. s. (2004). Non-timber forest product extraction: effects of harvest and browsing on an understory palm. Ecological Applications, 14 (4), 1139-1153. http://dx.doi.org/10.1890/02-5365

Ferroukhi, L., \& Echeverría, R. (2003). Las políticas de getión forestal descentralizada en Guatemala. In L. Ferroukhi (Ed.) Municipal forest management in latin America. CIFOR/IDRC, Bogor, Indonesia. [Online] Available: http://web.idrc.ca/es/ev-28161-201-1-DO_TOPIC.html

Gomez, I., \& Mendez, E. V. (2007). Association of forest communities of Peten, Guatemala. Context, accomplishments and challenges. [Online] Available: http://www.cifor.org/nc/online-library/browse/view-publication/publication/2464.html

Hodel, D. R. (1992). Chamaedorea palms. The species and their cultivation. Allen Press, Inc., Kansas.

Jones, F. A., \& Gorchov, D. L. (2000). Patterns of abundance and human use of the vulnerable understory palm Chamaedorea radicalis (Arecaceae), in a montane cloud forest, Tamaulipas, Mexico. Southwestern Naturalist, 45, 421-430. http://dx.doi.org/10.2307/3672590

Nesheim, I., Dhillion, S. S., \& Stølen, K. A. (2006). What happens to traditional knowledge and use of natural resources when people migrate? Human Ecology, 34, 99-131. http://dx.doi.org/10.1007/s10745-005-9004-y

New Agriculturist. (2010). Custodians of the forest - women in Guatemala. New Agriculturist, WRENmedia. [Online] Available: http://www.new-ag.info/en/focus/focusItem.php?a=1747

Nyomora, A. M. S., \& Mwasha, A. (2007). Indigenous vegetable crops of Tanzania: Research and development needs. In M. L. Chadha, G. Kuo, \& C. L. L. Gowda (Eds.) Proceedings of the 1st International Conference on Indigenous Vegetables and Legumes Prospectus for Fighting Poverty, Hunger and Malnutrition. 609-613.

O'Brien, T. G., \& Kinnaird, M. F. (1996). Effect of harvest on leaf development of the Asian palm Livistona rotundifolia. Conservation Biology, 10, 53-58. http://dx.doi.org/10.1046/j.1523-1739.1996.10010053.x

Pattanayak, S. K., \& Sills, E. O. (2001). Do tropical forests provide natural insurance? The microeconomics of non-timber forest product collection in the Brazilian Amazon. Land Economics, 77 (4), 595-613. http://dx.doi.org/10.2307/3146943

Penn, M. G., Moncrieff, C. B., Bridgewater, S. G. M., Garwood, N. C., Bateman, R. M., Chan, I., \& Cho, P. (2009). Using GIS techniques to model the distribution of the economically important xate palm Chamaedorea ernesti-augusti within the Greater Maya Mountains, Belize. Systematics and Biodiversity, 7 (1), 63-72. http://dx.doi.org/10.1017/S1477200008002880 
Pichon, F. J. (1997). Settler households and land-use patterns in the Amazon frontier: Farm-level evidence from Ecuador. World Development, 25 (1), 67-91. http://dx.doi.org/10.1016/S0305-750X(96)00091-5

Pyhala, A., Brown, K., \& Adger, W. N. (2006). Implications of livelihood dependence on non-timber products in Peruvian Amazonia. Ecosystems, 9 (8), 1328-1341. http://dx.doi.org/10.1007/s10021-005-0154-y

Radchowsky, J., Ramos, V. H. K. G., López J., \& Fajardo, A. (2004). Effects of managed extraction on populations of the understorey palm, xaté (Chamaedorea sp.) in northern Guatemala: Monitoring ecological integrity of the Maya Biosphere Reserve, Petén, Guatemala. Report. Wildlife Conservation Society.

Rainforest Alliance. (2006). [Online] Available: http://www.rainforest-alliance.org/news/2005/jade_leaf_span.html

Rainforest Alliance. (2010). Ornamental Greens from the Maya Biosphere Reserve: The Rainforest Alliance's Certified Xate [nitiative. Available: http://www.cinram.umn.edu/ecopalms/News\&Documents/RA_xate_profile.pdf

Reining, C. C. S., \& Heinzman, R. M. (1992). Nontimber forest products in the Petén, Guatemala: Why extractive reserves are critical for both conservation and development. In M. Plotkin, \& L. Famolare (Eds.) Sustainable harvest and marketing of rain forest products. Island Press, Washington DC. 110-117.

Reining, C. C. S., Heinzman, R. M., Madrid, M. C., López, S., \& Solórzano, A. (1992). Non timber products of the Maya Biosphere Reserve, Petén, Guatemala. Conservation International Foundation, Washington, DC.

Salafsky, N., Dugelby, B. L., \& Terborgh, J. W. (1993). Can extractive reserves save the rainforest? An ecological and socioeconomic comparison of nontimber forest product extraction systems in Petén, Guatemala, and East Kalimantan, Indonesia. Conservation Biology, 7, 39-52. http://dx.doi.org/10.1046/j.1523-1739.1993.07010039.x

Sánchez-Carillo, D., \& Valtierra-Pacheco, E. (2003). Social organization for the exploitation of Camedor palms (Chamaedorea spp.) in the Lacandona rainforest, Chiapas. Agrociencia, 37, 545-552. [Online] Available: http://openagricola.nal.usda.gov/Record/IND43676361

Schwartz, N. B. (1990). Forest society, a social history of Petén, Guatemala. University of Pennsylvania Press, Philadelphia.

Stølen, K. A. (2007). Guatemalans in the Aftermath of Violence: Refugees' Return. Pennsylvania University Press. [Online] Available: http://www.upenn.edu/pennpress/book/14346.html

Sunderlin, W. D., Angelsen, A., Belcher, B., Burgers, P., Nasi, R., Santoso, L., \& Wunder, S. (2005). Livelihoods, forests, and conservation in developing countries: An overview. World Development, 33 (9), 1383-1402, http://dx.doi.org/10.1016/j.worlddev.2004.10.004

Svenning, J.-C. (1999). Microhabitat specialization in species-rich palm community in Amazonian Ecuador. Journal of Ecology, 87, 55-65. http://dx.doi.org/10.1046/j.1365-2745.1999.00329.x

Taylor, P. L. (2010). Conservation, community, and culture? New organizational challenges of community forest concessions in the Maya Biosphere Reserve of Guatemala. Journal of Rural Studies, 26 (2), 173-184. http://dx.doi.org/10.1016/j.jrurstud.2009.09.006

Ticktin, T. (2004). The ecological implications of harvesting non-timber forest products. Journal of Applied Ecology, 41 (1), 11-21. http://dx.doi.org/10.1111/j.1365-2664.2004.00859.x

USAID. (2006). El rol de los productos naturales en el desarrollo rural, el alivio a la pobreza y gobernabilidad en el manejo del recurso. El caso de la palma de xate (Chamaedorea spp.) en la región de Petén, Guatemala. Pp. 74. International Resources Group, Washington DC.

Van der Vaeren P. (2000). Perdidos en la selva. Thela Publishers, Amsterdam. Available: http://www.powells.com/biblio/9789055380572

Wilsey, D. S., \& Hildebrand, P. E. (2011). Chamaedorea Palm Frond Commercialization and Certification Considered from a Smallholder Livelihood System Perspective. Small-Scale Forestry, 10 (1), 67-81. http://dx.doi.org/10.1007/s11842-010-9131-1

Ybarra, M. (2009). Violent visions of an ownership society: The land administration project in Peten, Guatemala. Land Use Policy, 26 (1), 44-54. http://dx.doi.org/10.1016/j.landusepol.2008.01.001 


\section{Notes}

Note 1. Their own standards were set with reference to their living conditions in the refugee camps in Mexico.

Note 2. The term "refugees" are used here as it refers to the time in Mexico.

Table 1. Number of xate bundles being sold per year, and mean values based on number of sales days

\begin{tabular}{ccccccc}
\hline Year & $\begin{array}{c}\text { C. } \\
\text { elegans }\end{array}$ & $\begin{array}{c}\text { Mean values } \\
\text { C. elegans }\end{array}$ & $\begin{array}{c}\text { C. } \\
\text { oblongata }\end{array}$ & $\begin{array}{c}\text { Mean values C. } \\
\text { oblongata }\end{array}$ & $\begin{array}{c}\text { C. } \\
\text { ernesti-augusti }\end{array}$ & $\begin{array}{c}\text { Mean values C. } \\
\text { ernesti-augusti }\end{array}$ \\
\hline 1998 & 15197.0 & 330 & 15659.0 & 340 & 5492.0 & 119 \\
1999 & 16822.5 & 358 & 15320.5 & 326 & 5775.5 & 123 \\
2000 & 7534.0 & 301 & 6746.5 & 270 & 2303.0 & 92 \\
\hline
\end{tabular}

Table 2. Total number of adults, and juveniles, harvested plants and number of cuts for Chamaedorea elegans (C.e.), C. oblongata (C.o.) C. ernesti-augusti (C.e-a.) in each of the plots. Total xate density in plots (sum xate ind.)

\begin{tabular}{|c|c|c|c|c|c|c|c|c|c|c|c|c|c|}
\hline Plot & $\begin{array}{l}\text { C. } \\
\text { e. }\end{array}$ & $\begin{array}{c}\text { C. e. } \\
\text { juvenil } \\
\text { es }\end{array}$ & $\begin{array}{l}\text { C. e. } \\
\text { no. } \\
\text { harve } \\
\text { st. }\end{array}$ & $\begin{array}{l}\text { C. } \\
\text { e. } \\
\text { no. } \\
\text { cut } \\
\text { s }\end{array}$ & $\begin{array}{l}\text { C. } \\
\text { o. }\end{array}$ & $\begin{array}{c}\text { C. o. } \\
\text { juvenil } \\
\text { es }\end{array}$ & $\begin{array}{c}\text { C. o. } \\
\text { no. } \\
\text { harve } \\
\text { st. }\end{array}$ & $\begin{array}{l}\text { C. } \\
\text { o. } \\
\text { no. } \\
\text { cut } \\
\text { s }\end{array}$ & $\begin{array}{l}\text { C. } \\
\text { e- } \\
\text { a. }\end{array}$ & $\begin{array}{c}\text { C. e-a. } \\
\text { juvenil } \\
\text { es }\end{array}$ & $\begin{array}{c}\text { C. } \\
\text { e-a. } \\
\text { no. } \\
\text { harve } \\
\text { st. }\end{array}$ & $\begin{array}{l}\text { C. } \\
\text { e-a. } \\
\text { no. } \\
\text { cuts }\end{array}$ & $\begin{array}{c}\mathrm{Su} \\
\mathrm{m} \\
\text { xat } \\
\mathrm{e} \\
\text { ind. }\end{array}$ \\
\hline Reserve 1 & 12 & 2 & 0 & 0 & 94 & 36 & 0 & 0 & 0 & 0 & 0 & 0 & 144 \\
\hline Reserve 2 & 24 & 4 & 0 & 0 & 119 & 368 & 0 & 0 & 0 & 0 & 0 & 0 & 515 \\
\hline $\begin{array}{c}\text { Logging } \\
3\end{array}$ & $\begin{array}{c}15 \\
1\end{array}$ & 55 & 73 & $\begin{array}{c}19 \\
0\end{array}$ & 421 & 170 & 13 & 26 & 1 & 2 & 0 & 0 & 797 \\
\hline$\underset{4}{\text { Logging }}$ & 98 & 20 & 37 & 68 & 219 & 64 & 9 & 11 & 10 & 1 & 2 & 2 & 411 \\
\hline $\begin{array}{l}\text { Settlemen } \\
\text { t } 5\end{array}$ & $\begin{array}{c}90 \\
1\end{array}$ & 186 & 475 & $\begin{array}{c}98 \\
1\end{array}$ & $\begin{array}{c}170 \\
0\end{array}$ & 347 & 594 & $\begin{array}{c}104 \\
2\end{array}$ & $\begin{array}{c}32 \\
2\end{array}$ & 156 & 221 & 482 & $\begin{array}{c}361 \\
2\end{array}$ \\
\hline
\end{tabular}




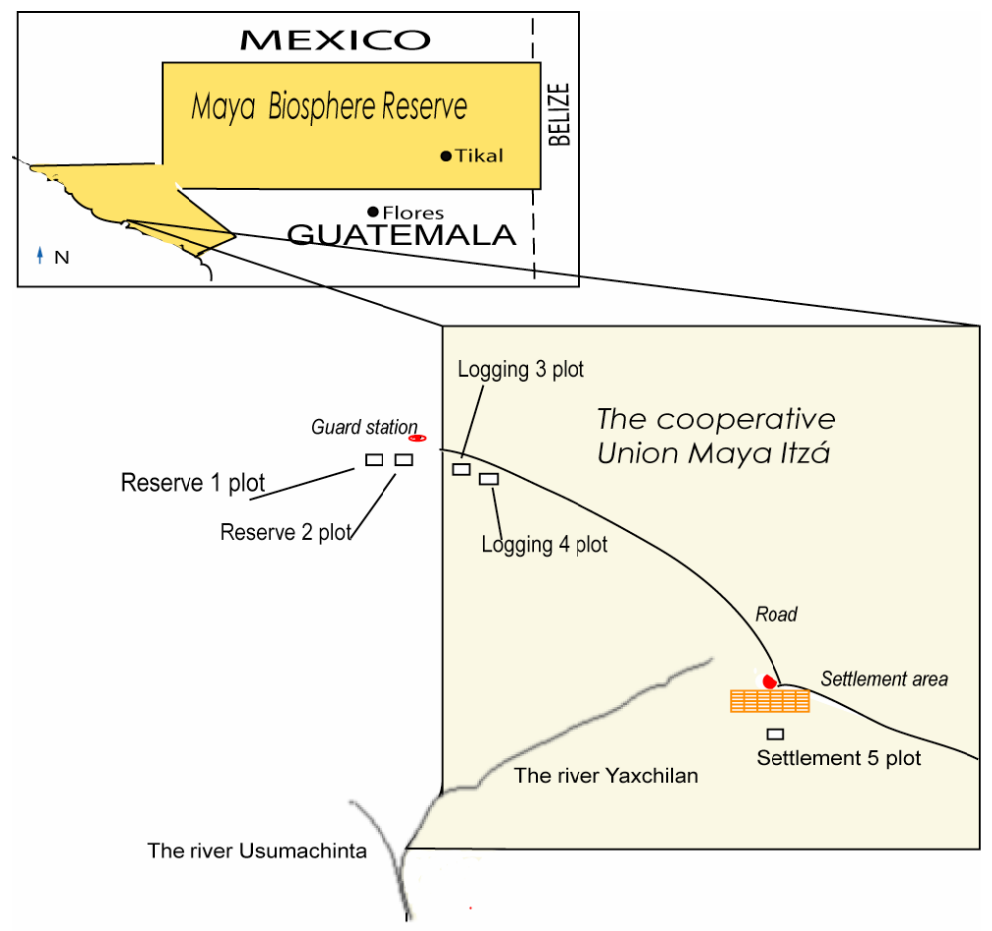

Figure 1. Location of the study area in the MBR and in the cooperative UMI. The plots were placed in three different disturbance regimes, within the protected part of the reserve, (Reserve 1 and Reserve 2 plots) in a logged area of high disturbance (Logging 3 and Logging 4 plots) and close to the settlement area of intermediate disturbance (Settlement 5 plot)

Jade 1998 Number of people selling xate in 1998
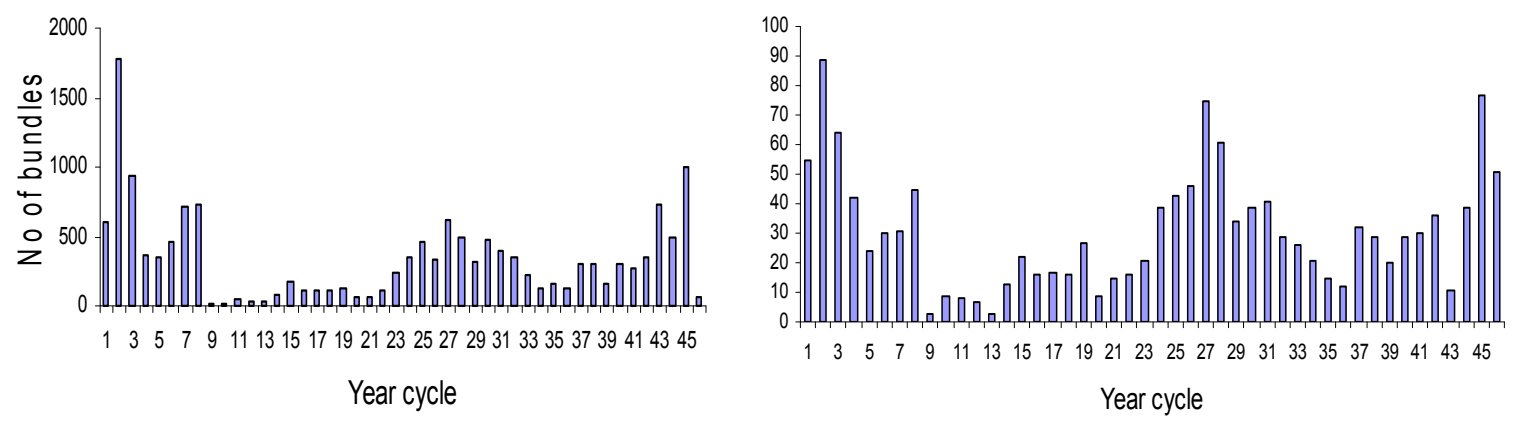

Figure 2a. The variation in number of C. oblongata bundles sold on sales days in 1998 
Number of people selling xate in 1998

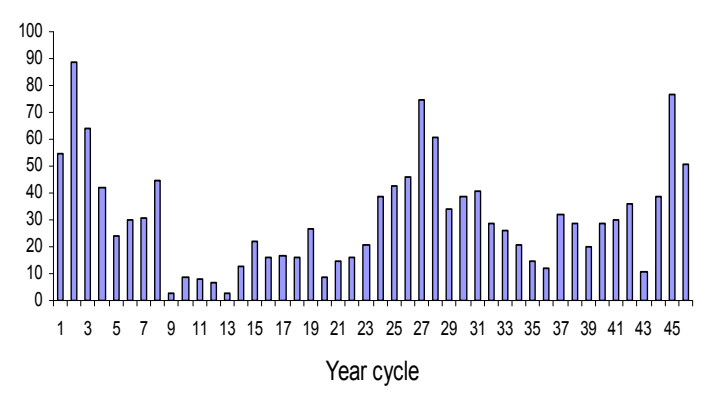

Figure 2b. The number of people selling xate on sales days in 1998
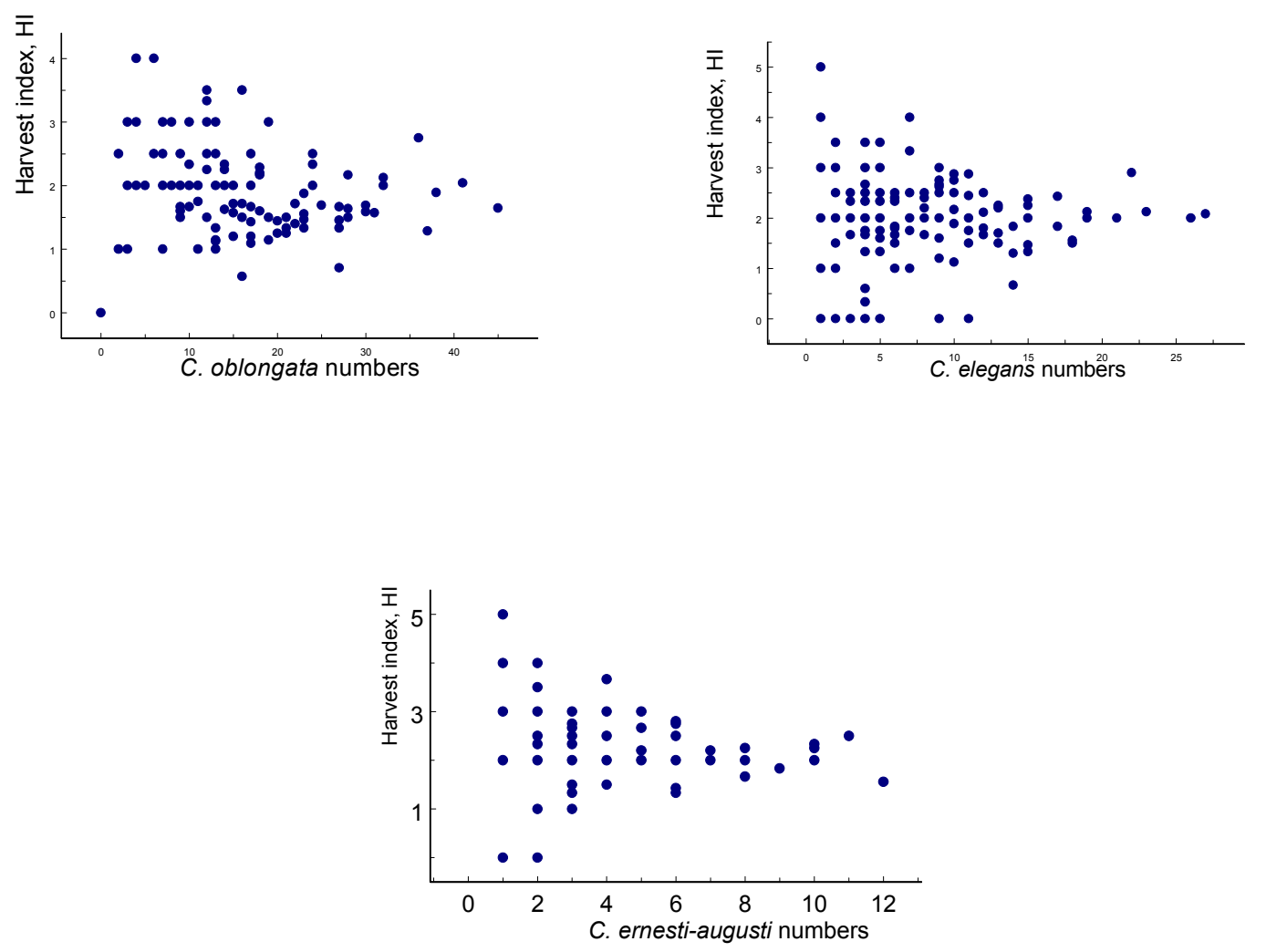

Figure 3. H.I. index at different density levels in the Settlement 5 plot: a) for Chamaedorea oblongata, b) for $C$. elegans, and c) for C. ernesti-augusti 